\title{
Wind energy literature survey no. 34
}

\section{Pavese, Christian}

\section{Published in: \\ Wind Energy}

Link to article, DOI:

10.1002/we.1813

Publication date:

2015

Document Version

Publisher's PDF, also known as Version of record

Link back to DTU Orbit

Citation (APA):

Pavese, C. (2015). Wind energy literature survey no. 34. Wind Energy, 18, 1313-1316.

https://doi.org/10.1002/we.1813

\section{General rights}

Copyright and moral rights for the publications made accessible in the public portal are retained by the authors and/or other copyright owners and it is a condition of accessing publications that users recognise and abide by the legal requirements associated with these rights.

- Users may download and print one copy of any publication from the public portal for the purpose of private study or research.

- You may not further distribute the material or use it for any profit-making activity or commercial gain

- You may freely distribute the URL identifying the publication in the public portal

If you believe that this document breaches copyright please contact us providing details, and we will remove access to the work immediately and investigate your claim. 


\title{
LITERATURE SURVEY
}

\section{Wind energy literature survey no. 34}

\author{
Christian Pavese \\ Department of Wind Energy, Technical University of Denmark, Roskilde, Denmark
}

\begin{abstract}
As a service to readers, Wind Energy regularly conducts literature surveys and publishes lists of relevant articles drawn from recent issues of Wind Energy itself and a large number of periodicals including Journal of Wind Engineering and Industrial Aerodynamics, International Journal of Energy Research, Renewable Energy, Energy Sources, Journal of Solar Energy Engineering, American Institute of Aeronautics and Astronautics Journal, Electric Power Components and Systems along with a number of periodicals published by the Institute of Electrical and Electronics Engineers, etc. The list is limited exclusively to journals not specifically devoted to wind energy and its applications. To assist the reader, the list is separated into broad categories. Although many papers fit several categories, each paper is listed only once under the category thought most appropriate. Please note that the inclusion in the list is not an endorsement of a paper's quality. Compiled by Christian Pavese, Department of Wind Energy, Technical University of Denmark, PO 49, DK-4000 Roskilde, Denmark. Please email any suggestions to cpav@dtu.dk. Copyright @ 2014 John Wiley \& Sons, Ltd.
\end{abstract}

\section{KEYWORDS}

Literature Survey; Wind Energy

Correspondence

Christian Pavese, Department of Wind Energy, Technical University of Denmark, Roskilde, Denmark.

E-mail: cpav@dtu.dk

Received 9 August 2014; Accepted 16 September 2014

\section{AERODYNAMICS, AEROELASTICS, AEROACOUSTICS AND NOVEL WIND ENERGY CONVERSION CONCEPTS}

Abdelsalam AM, Boopathi K, Gomathinayagam S, Kumar SSHK, Ramalingam V. Experimental and numerical studies on the wake behavior of a horizontal axis wind turbine. Journal of Wind Engineering and Industrial Aerodynamics 2014; 128: 54-65.

Akay B, Ragni D, Ferreira CJS, Bussel GJW. Experimental investigation of the root flow in a horizontal axis wind turbine. Wind Energy 2014; 17: 1093-1109. Biswas A, Gupta R. Unsteady aerodynamics of a twist bladed H-Darrieus rotor in low Reynolds number flow. Journal of Renewable and Sustainable Energy 2014; 6: 033108

Dyachuk E, Goude A, Bernhoff H. Dynamic stall modeling for the conditions of vertical axis wind turbines. AIAA Journal 2014; 52: 72-81.

Elfarra MA, Sezer-Uzol N, Akmandor IS. NREL VI rotor blade: numerical investigation and winglet design and optimization using CFD. Wind Energy 2014; 17: $605-626$.

Greenblatt D, Ben-Harav A, Mueller-Vahl H. Dynamic stall control on a vertical-axis wind turbine using plasma actuators. AIAA Journal 2014; 52: 456-462. Hjort S, Larsen H. A multi-element diffuser augmented wind turbine. Energies 2014; 7: 3256-3281.

Jeong M-S, Kim S-W, Lee I, Yoo S-J, Park KC. Investigation of wake effects on aeroelastic responses of horizontal-axis wind-turbines. AIAA Journal 2014; 52: AIAA; ASME; ASCE; AHS; ASC.

Li X, Yang K, Zhang L, Bai J, Xu J. Large thickness airfoils with high lift in the operating range of angle of attack. Journal of Renewable and Sustainable Energy 2014; 6: 033110.

Peters DA, Modarres R. A compact, closed-form solution for the optimum, ideal wind turbine. Wind Energy 2014; 17: 589-603.

Ren N, Li Y, Ou J. Coupled wind-wave time domain analysis of floating offshore wind turbine based on computational fluid dynamics method. Journal of Renewable and Sustainable Energy 2014; 6: 023106.

Rockel S, Camp E, Schmidt J, Peinke J, Cal RB, Hoelling M. Experimental study on influence of pitch motion on the wake of a floating wind turbine model. Energies 2014; 7: 1954-1985.

Shamsoddin S, Porte-Agel F. Large eddy simulation of vertical axis wind turbine wakes. Energies 2014; 7: 890-912.

Si Y, Karimi HR, Gao H. Modelling and optimization of a passive structural control design for a spar-type floating wind turbine. Engineering Structures 2014; 69: 168-182. Skrzypinski WR, Gaunaa M, Sorensen N, Zahle F, Heinz J. Self-induced vibrations of a DU96-W-180 airfoil in stall. Wind Energy 2014; 17: 641-655.

Troldborg N, Sorensen JN, Mikkelsen R, Sorensen NN. A simple atmospheric boundary layer model applied to large eddy simulations of wind turbine wakes. Wind Energy 2014; 17: 657-669. 
Vorpahl F, Strobel M, Jonkman JM, Larsen TJ, Passon P, Nichols J. Verification of aero-elastic offshore wind turbine design codes under IEA Wind Task XXIII. Wind Energy 2014; 17: 519-547.

Wood DH. Ideal wind turbine performance at very low tip speed ratio. Journal of Renewable and Sustainable Energy $2014 ; \mathbf{6}$ : 033115.

\section{STRUCTURES, LOADS, FATIGUE AND MECHANICAL COMPONENTS}

Bottasso CL, Campagnolo F, Croce A, Dilli S, Gualdoni F, Nielsen MB. Structural optimization of wind turbine rotor blades by multilevel sectional/multibody/3D-FEM analysis. Multibody System Dynamics 2014; 32: 87-116.

Chen X, Zhao W, Zhao XL, Xu JZ. Failure test and finite element simulation of a large wind turbine composite blade under static loading. Energies 2014 ; 7: $2274-2297$. Jeong M-S, Cha M-C, Kim S-W, Lee I, Kim T. Effects of torsional degree of freedom, geometric nonlinearity, and gravity on aeroelastic behavior of large-scale horizontal axis wind turbine blades under varying wind speed conditions. Journal of Renewable and Sustainable Energy 2014 ; 6: 023126. Lee HG, Park J. Linear relationship of damping ratios in resonance-type fatigue testing of a wind turbine blade. Wind Energy 2014; 17: 1119-1122.

Li AJ, Tang BY, Yeung CRW. Effects of second-order difference-frequency wave forces on a new floating platform for an offshore wind turbine. Journal of Renewable and Sustainable Energy 2014; 6: 033102.

Marquez-Dominguez S, Sorensen JD. Fatigue reliability and calibration of fatigue design factors for offshore wind turbines (vol 5, pg 1816, 2012). Energies 2014; 7: 2146-2147.

Nematbakhsh A, Olinger DJ, Tryggvason G. Nonlinear simulation of a spar buoy floating wind turbine under extreme ocean conditions. Journal of Renewable and Sustainable Energy 2014; 6: 033121.

Prowell I, Elgamal A, Uang C-M, Luco JE, Romanowitz H, Duggan E. Shake table testing and numerical simulation of a utility-scale wind turbine including operational effects. Wind Energy 2014; 17: 997-1016.

Segeren MLA, Lourens E-M, Tsouvalas A, van der Zee TJJ. Investigation of a slip joint connection between the monopile and the tower of an offshore wind turbine. IET Renewable Power Generation 2014; 8: 422-432.

Stubkier S, Pedersen HC, Jonkman JM. Analysis of load reduction possibilities using a hydraulic soft yaw system for a 5-MW turbine and its sensitivity to yaw-bearing friction. Engineering Structures 2014; 69: 123-134.

Voormeeren SN, Valk PLC, Nortier BP, Molenaar DP, Rixen DJ. Accurate and efficient modeling of complex offshore wind turbine support structures using augmented superelements. Wind Energy 2014; 17: 1035-1054.

Xing Y, Karimirad M, Moan T. Modelling and analysis of floating spar-type wind turbine drivetrain. Wind Energy 2014; 17: 565-587.

Zhu J, Cai X, Pan P, Gu R. Multi-objective structural optimization design of horizontal-axis wind turbine blades using the non-dominated sorting genetic algorithm II and finite element method. Energies 2014; 7: 988-1002.

\section{FORECASTING, WIND RESOURCES, TURBULENCE MODELLING AND ANEMOMETRY}

Aitken ML, Kosovic B, Mirocha JD, Lundquist JK. Large eddy simulation of wind turbine wake dynamics in the stable boundary layer using the Weather Research and Forecasting Model. Journal of Renewable and Sustainable Energy 2014; 6: 033137.

Azad AK, Rasul MG, Yusaf T. Statistical diagnosis of the best Weibull methods for wind power assessment for agricultural applications. Energies 2014; 7: 3056-3085.

Carrillo C, Cidras J, Diaz-Dorado E, Felipe Obando-Montano A. An approach to determine the Weibull parameters for wind energy analysis: the case of Galicia (Spain). Energies 2014; 7: 2676-2700.

Chang R, Zhu R, Badger M, Hasager CB, Zhou R, Ye D, Zhang X. Applicability of synthetic aperture radar wind retrievals on offshore wind resources assessment in Hangzhou Bay, China. Energies 2014; 7: 3339-3354.

Janjai S, Masiri I, Promsen W, Pattarapanitchai S, Pankaew P, Laksanaboonsong J, Bischoff-Gauss I, Kalthoff N. Evaluation of wind energy potential over Thailand by using an atmospheric mesoscale model and a GIS approach. Journal of Wind Engineering and Industrial Aerodynamics 2014; 129: 1-10.

Kelly M, Troen I, Jorgensen HE. Weibull-k revisited: "Tall" profiles and height variation of wind statistics. Boundary-layer Meteorology 2014 ; 152: 107-124.

Li Y, Li W, Yan W, Yu J, Zhao X. Probabilistic optimal power flow considering correlations of wind speeds following different distributions. IEEE Transactions on Power Systems 2014; 29: 1847-1854.

Melius MS, Tutkun M, Cal RB. Identification of Markov process within a wind turbine array boundary layer. Journal of Renewable and Sustainable Energy 2014; 6: 023121 .

Saavedra-Moreno B, Salcedo-Sanz S, Casanova-Mateo C, Portilla-Figueras JA, Prieto L. Heuristic correction of wind speed mesoscale models simulations for wind farms prospecting and micrositing. Journal of Wind Engineering and Industrial Aerodynamics 2014; 130: 1-15.

Salmon J, Taylor P. Errors and uncertainties associated with missing wind data and short records. Wind Energy 2014; 17: 1111-1118.

Weekes SM, Tomlin AS. Low-cost wind resource assessment for small-scale turbine installations using site pre-screening and short-term wind measurements. IET Renewable Power Generation 2014; 8: 349-358.

Zhang M, Liu M. Investigation of the wind resource assessment over 2D continuous rolling hills due to tropical cyclones in the coastal region of Southeastern China. Energies 2014; 7: 913-933.

\section{CONTROL AND CONDITION MONITORING}

Carcangiu CE, Pujana-Arrese A, Mendizabal A, Pineda I, Landaluze J. Wind gust detection and load mitigation using artificial neural networks assisted control. Wind Energy 2014; 17: 957-970.

Castaignet D, Barlas T, Buhl T, Poulsen NK, Wedel-Heinen JJ, Olesen NA, Bak C, Kim T. Full-scale test of trailing edge flaps on a Vestas V27 wind turbine: active load reduction and system identification. Wind Energy 2014; 17: 549-564.

Chen J-H, Yau H-T, Hung W. Design and study on sliding mode extremum seeking control of the chaos embedded particle swarm optimization for maximum power point tracking in wind power systems. Energies 2014; 7: 1706-1720.

Devriendt C, Weijtjens W, El-Kafafy M, De Sitter G. Monitoring resonant frequencies and damping values of an offshore wind turbine in parked conditions. IET Renewable Power Generation 2014; 8: 433-441. 
Dinwoodie IA, McMillan D. Operational strategies for offshore wind turbines to mitigate failure rate uncertainty on operational costs and revenue. IET Renewable Power Generation 2014; 8: 359-366.

Dong X, Lian J, Yang M, Wang H. Operational modal identification of offshore wind turbine structure based on modified stochastic subspace identification method considering harmonic interference. Journal of Renewable and Sustainable Energy 2014; 6: 033128.

Elhassan Z, Yi T, Yang L. Comparative study of voltage oriented and frequency coordinated control of grid connected doubly fed induction generator. Journal of Renewable and Sustainable Energy 2014; 6: 023120.

Fagiano L, Zgraggen AU, Morari M, Khammash M. Automatic crosswind flight of tethered wings for airborne wind energy: modeling, control design, and experimental results. IEEE Transactions on Control Systems Technology 2014; 23: 1433-1447.

Gros S, Chachuat B. Optimization-based load reduction during rapid shutdown of multi-megawatt wind turbine generators. Wind Energy 2014; 17: $1055-1075$.

Kragh KA, Hansen MH. Load alleviation of wind turbines by yaw misalignment. Wind Energy 2014; 17: 971-982.

McKay PM, Carriveau R, Ting DSK, Johrendt JL. Global sensitivity analysis of wind turbine power output. Wind Energy 2014; 17: 983-995.

Milan P, Waechter M, Peinke J. Stochastic modeling and performance monitoring of wind farm power production. Journal of Renewable and Sustainable Energy 2014; 6: 033119 .

Mohammadi E, Fadaeinedjad R, Moallem M. A new control strategy to suppress the tower vibrations of variable speed wind turbines. Journal of Renewable and Sustainable Energy 2014; 6: 033106.

Perng J-W, Chen G-Y, Hsieh S-C. Optimal PID controller design based on PSO-RBFNN for wind turbine systems. Energies 2014; 7: $191-209$.

Satpathy AS, Kishore NK, Kastha D, Sahoo NC. Control scheme for a stand-alone wind energy conversion system. IEEE Transactions on Energy Conversion 2014; 29: 418-425.

Shi Y-T, Kou Q, Sun D-H, Li Z-X, Qiao S-J, Hou Y-J. H-infinity fault tolerant control of WECS based on the PWA model. Energies 2014; 7: 1750-1769. Tchakoua P, Wamkeue R, Ouhrouche M, Slaoui-Hasnaoui F, Tameghe TA, Ekemb G. Wind turbine condition monitoring: state-of-the-art review, new trends, and future challenges. Energies 2014; 7: 2595-2630.

Wilkinson M, Darnell B, van Delft T, Harman K. Comparison of methods for wind turbine condition monitoring with SCADA data. IET Renewable Power Generation 2014; 8: 390-397.

Yampikulsakul N, Byon E, Huang S, Sheng S, You M. Condition monitoring of wind power system with nonparametric regression analysis. IEEE Transactions ON Energy Conversion 2014; 29: 288-299.

Yan Y, Li J, Gao DW. Condition parameter modeling for anomaly detection in wind turbines. Energies 2014; 7: 3104-3120.

Yin S, Wang G, Karimi HR. Data-driven design of robust fault detection system for wind turbines. Mechatronics 2014; 24: $298-306$.

Yunqi X, Kunpeng W, Guanju H, Xiyun Y. An operating condition fuzzy assessment strategy for large scale doubly-fed wind power generation system. Journal of Renewable and Sustainable Energy 2014; 6: 033111.

Zhao B, Li H, Wang M, Chen Y, Liu S, Yang D, Yang C, Hu Y, Chen Z. An optimal reactive power control strategy for a DFIG-based wind farm to damp the sub-synchronous oscillation of a power system. Energies 2014; 7: 3086-3103.

\section{GRID CONNECTION AND ELECTRICAL COMPONENTS}

Basu B, Staino A, Basu M. Role of flexible alternating current transmission systems devices in mitigating grid fault-induced vibration of wind turbines. Wind Energy 2014; 17: 1017-1033.

Elserougi AA, Massoud AM, Abdel-Khalik AS, Ahmed S. Bidirectional buck-boost inverter-based HVDC transmission system with AC-side contribution blocking capability during DC-side faults. IEEE Transactions on Power Delivery 2014; 29: 1249-1261.

Goksu O, Teodorescu R, Bak CL, Iov F, Kjaer PC. Instability of wind turbine converters during current injection to low voltage grid faults and PLL frequency based stability solution. IEEE Transactions on Power Systems 2014; 29: 1683-1691.

Laguna AJ, Diepeveen NFB, van Wingerden JW. Analysis of dynamics of fluid power drive-trains for variable speed wind turbines: parameter study. IET Renewable Power Generation 2014; 8: 398-410.

Li H, Yang C, Hu Y, Zhao M, Zhao B, Chen Z, Liu S, Yang D. Model and performance of current sensor observers for a doubly fed induction generator. Electric Power Components and Systems 2014; 42: 1048-1058.

Li S. Operation region of doubly fed induction generators based on rotor slip under maximum power point tracking control and power dispatch. Electric Power Components and Systems 2014; 42: 808-817.

Namjoo N, Abbasi F, Hassanzadeh F, Asrari H, Hajizadeh A. A new hybrid control method for controlling back-to-back converter in permanent magnet synchronous generator wind turbines. Journal of Renewable and Sustainable Energy 2014; 6: 033133.

Pico HNV, Aliprantis DC. Voltage ride-through capability verification of wind turbines with fully-rated converters using reachability analysis. IEEE Transactions on Energy Conversion 2014; 29: 392-405.

Rashid G, Ali MH. A modified bridge-type fault current limiter for fault ride-through capacity enhancement of fixed speed wind generator. IEEE Transactions on Energy Conversion 2014; 29: 527-534.

Rodriguez Arribas J, Fernandez Rodriguez A, Hermoso Munoz A, Veganzones NC. Low voltage ride-through in DFIG wind generators by controlling the rotor current without crowbars. Energies 2014; 7: 498-519.

Santoso S, Lwin M, Ramos J, Singh M, Muljadi E, Jonkman J. Designing and integrating wind power laboratory experiments in power and energy systems courses. IEEE Transactions on Power Systems 2014; 29: 1944-1951.

Shehata EG. Direct power control of wind-turbine-driven DFIG during transient grid voltage unbalance. Wind Energy 2014; 17: 1077-1091.

Zappala D, Tavner PJ, Crabtree CJ, Sheng S. Side-band algorithm for automatic wind turbine gearbox fault detection and diagnosis. IET Renewable Power Generation 2014; 8: 380-389.

\section{WIND FARMS}

Ahmed MA, Kim Y-C. Hierarchical communication network architectures for offshore wind power farms. Energies 2014; 7: 3420-3437.

Castellani F, Garinei A, Terzi L, Astolfi D, Gaudiosi M. Improving windfarm operation practice through numerical modelling and supervisory control and data acquisition data analysis. IET Renewable Power Generation 2014; 8: 367-379. 
Dobric G, Durisic Z. Double-stage genetic algorithm for wind farm layout optimization on complex terrains. Journal of Renewable and Sustainable Energy 2014; 6: 033127.

Gayme DF, Chakrabortty A. A spatio-temporal framework for spectral analysis and control of interarea oscillations in wind-integrated power systems. IEEE Transactions on Control Systems Technology 2014; 23: 1658-1665.

Ghadirian A, Dehghan M, Torabi F. Considering induction factor using BEM method in wind farm layout optimization. Journal of Wind Engineering and Industrial Aerodynamics 2014; 129: 31-39.

He M, Yang L, Zhang J, Vittal V. A spatio-temporal analysis approach for short-term forecast of wind farm generation. IEEE Transactions on Power Systems 2014; 29: 1611-1622.

Konstantinidis EI, Kompolias DG, Botsaris PN. Viability analysis of an offshore wind farm in North Aegean Sea, Greece. Journal of Renewable and Sustainable Energy 2014; 6: 023116.

Soleimanzadeh M, Wisniewski R, Brand A. State-space representation of the wind flow model in wind farms. Wind Energy 2014; 17: 627-639.

Stevens RJAM, Gayme DF, Meneveau C. Large eddy simulation studies of the effects of alignment and wind farm length. Journal of Renewable and Sustainable Energy 2014; 6: 023105.

\section{GRID INTEGRATION AND ECONOMICS}

Abadie LM, Chamorro JM. Valuation of Wind Energy Projects: a real options approach. Energies 2014; 7: 3218-3255.

Ahmadi-Khatir A, Conejo AJ, Cherkaoui R. Multi-area unit scheduling and reserve allocation under wind power uncertainty. IEEE Transactions on Power Systems 2014; 29: 1701-1710.

Alamelu SM, Baskar S, Babulal CK, Jeyadevi S. Optimal siting and sizing of unified power flow controller using covariance matrix adapted evolution strategy in grid integrated wind energy conversion systems. Journal of Renewable and Sustainable Energy 2014; 6: 023119.

Alsayed M, Cacciato M, Scarcella G, Scelba G. Design of hybrid power generation systems based on multi criteria decision analysis. Solar Energy 2014; 105: $548-560$.

Askari MT, Ab Kadir MZA, Hizam H, Jasni J. A new comprehensive model to simulate the restructured power market for seasonal price signals by considering on the wind resources. Journal of Renewable and Sustainable Energy 2014; 6: 023104.

Ding T, Guo Q, Bo R, Sun H, Zhang B, Huang T-e. A static voltage security region for centralized wind power integration-part II: applications. Energies 2014; 7: 444-461.

Eminoglu U, Ayasun S. Modeling and design optimization of variable-speed wind turbine systems. Energies 2014; 7: 402-419.

Hou T, Lou S, Wu Y. Capacity optimization of thermal units transmitted with wind power: a case study of Jiuquan wind power base, China. Journal of Wind Engineering and Industrial Aerodynamics 2014; 129: 64-68.

Saebi J, Javidi MH. Economic evaluation of demand response in power systems with high wind power penetration. Journal of Renewable and Sustainable Energy 2014; 6: 033141.

Saiz-Marin E, Lobato E, Egido I. Local hosting capacity increase by means of wind farm voltage control provision. IEEE Transactions on Power Systems 2014; 29: 1731-1738.

Salih SN, Chen P, Carlson O, Tjernberg LB. Optimizing wind power hosting capacity of distribution systems using cost benefit analysis. IEEE Transactions on Power Delivery 2014; 29: 1436-1445.

Shafiee M, Dinmohammadi F. An FMEA-based risk assessment approach for wind turbine systems: a comparative study of onshore and offshore. Energies 2014; 7: 619-642.

U1 Haque A, Nehrir MH, Mandal P. A hybrid intelligent model for deterministic and quantile regression approach for probabilistic wind power forecasting. IEEE Transactions on Power Systems 2014; 29: 1663-1672.

Xie H, Li B, Heyman C, de Oliveira MM, Monge M. Subsynchronous resonance characteristics in presence of doubly-fed induction generator and series compensation and mitigation of subsynchronous resonance by proper control of series capacitor. IET Renewable Power Generation 2014; 8: 411-421. 